\title{
A survey on knowledge, attitude, and practice about \\ antibiotic prescribing and resistance among medical
}

\section{practitioners in Kenya [version 1; peer review: awaiting peer}

\section{review]}

\author{
Moses Kamita(D1, Joe Kimanthi Mutungi(D1,2, Samuel Mungai1, \\ Dominic Mureithi (i)3 ${ }^{3}$, Caroline Kijogi(i)1, Racheal Kimani ${ }^{1}$, Davies Ndegwa(i)4, \\ Jeremiah Maina1, Jesse Gitaka (D)1 \\ ${ }^{1}$ Directorate of Research and Innovation, Mount Kenya University, P.O. Box 342, Thika, 01000, Kenya \\ ${ }^{2}$ College of Basic and Applied Sciences, University of Ghana, P.O. Box LG 25, Legon, Accra, Ghana \\ ${ }^{3}$ Department of Animal Sciences, Chuka University, P.O. Box 109, Chuka, 60400, Kenya \\ ${ }^{4}$ Department of Medical Laboratory Sciences, Kenya Medical Training College, P.O. Box 30195, Nairobi, 00100, Kenya
}

V1 First published: 04 Feb 2022, 5:3
https://doi.org/10.12688/aasopenres.13328.1

Latest published: 04 Feb 2022, 5:3

https://doi.org/10.12688/aasopenres.13328.1

Abstract

\section{Background}

Antibiotic resistance is a growing global health threat worldwide and especially in developing countries. Irrational antibiotic prescription as well as lack of the requisite knowledge and awareness of proper antibiotic use are major drivers of antibiotic resistance. In Kenya, although the Ministry of Health has developed antibiotic use guidelines, these guidelines are not widely followed. Antibiotic prescription is, therefore, hugely at the discretion of the clinician. It is thus necessary to understand the knowledge, attitude, and practices (KAP) of antibiotic prescription among medical practitioners in the country. This study aimed to evaluate the knowledge, attitude, and practices (KAP) among antibiotic prescribers in three counties (Kiambu, Nakuru, and Bungoma) in Kenya.

\section{Methods}

This was a cross-sectional study using a self-administered questionnaire. Simple descriptive statistics were used to generate frequencies, percentages, and proportions. Where necessary, univariate analyses such as Pearson's chi-square were performed to compare proportions for statistical significance.

\section{Results}

From the three counties, 240 respondents recorded their responses: $30 \%$ from Kiambu, 34.6\% from Nakuru, and 35.4\% from Bungoma. The respondents included 19 (7.9\%) consultants, 66 (27.4\%) medical officers, 135 (56.3\%) clinical officers and 20 (8.3\%) pharmacists. Of all

\section{Open Peer Review}

Approval Status AWAITING PEER REVIEW

Any reports and responses or comments on the article can be found at the end of the article. 
respondents, more than $90 \%$ agreed or strongly agreed that antibiotic resistance (ABR) is a catastrophe worldwide and in Kenya. However, the proportion of the respondents who either agreed or strongly agreed (71.6\%) that antibiotic resistance is a problem in their respective health facilities was significantly lower $(\rho=0.013)$.

\section{Conclusion}

This study revealed that most medical practitioners were aware and knowledgeable about antibiotic resistance. However, there was a disconnect with mitigation measures such as active antibiotic stewardship and laboratory analyses to support judicious prescription. There is, therefore, a need for continuous education and stewardship interventions.

\section{Keywords}

antimicrobials, antimicrobial resistance, KAP-survey, Kenya, antibiotics, antibiotic prescription, medical practitioners

\section{Corresponding author: Jesse Gitaka (jgitaka@mku.ac.ke)}

Author roles: Kamita M: Data Curation, Formal Analysis, Investigation, Writing - Original Draft Preparation, Writing - Review \& Editing; Mutungi JK: Data Curation, Methodology, Writing - Review \& Editing; Mungai S: Data Curation, Methodology, Writing - Review \& Editing; Mureithi D: Data Curation, Investigation, Writing - Review \& Editing; Kijogi C: Data Curation, Methodology, Writing - Review \& Editing; Kimani R: Data Curation, Investigation, Writing - Review \& Editing; Ndegwa D: Data Curation, Methodology, Writing - Review \& Editing; Maina J: Data Curation, Methodology, Writing - Review \& Editing; Gitaka J: Conceptualization, Funding Acquisition, Methodology, Project Administration, Supervision

Competing interests: No competing interests were disclosed.

Grant information: This work was supported by The Kenya National Research Fund (grant number NRF/MKU/2017/007). Dr Jesse Gitaka is an Affiliate of the African Academy of Sciences.

The funders had no role in study design, data collection and analysis, decision to publish, or preparation of the manuscript.

Copyright: ( 2022 Kamita $\mathrm{M}$ et al. This is an open access article distributed under the terms of the Creative Commons Attribution License, which permits unrestricted use, distribution, and reproduction in any medium, provided the original work is properly cited.

How to cite this article: Kamita M, Mutungi JK, Mungai $S$ et al. A survey on knowledge, attitude, and practice about antibiotic prescribing and resistance among medical practitioners in Kenya [version 1; peer review: awaiting peer review] AAS Open Research 2022, 5:3 https://doi.org/10.12688/aasopenres.13328.1

First published: 04 Feb 2022, 5:3 https://doi.org/10.12688/aasopenres.13328.1 


\section{Introduction}

Antimicrobial resistance (AMR) happens when human, animal, or plant pathogens (viruses, bacteria, parasites, and fungi) are no longer responsive to treatment (antivirals, antibiotics, antiparasitic, and antifungals) that had been effective against them before $^{1}$. In humans, this makes treatment of common diseases difficult, increases the risk of disease severity, morbidity, and fatality. Indeed, antibiotic resistance (ABR) is a product of evolutionary dynamics driven by selection pressure and genetic mutations that confer a survival advantage to the bacteria ${ }^{2}$.

In low- and middle-income countries where the disease burden is already high and health systems are not well developed, antibiotic resistance and the resultant consequences are more pronounced. There is a problem of access to quality antibiotics on one hand and the problem of injudicious use of antibiotics on the other.

Studies have shown that in Africa, there are a lot of patients who do not receive antibiotics through the usual health care systems. More than $30 \%$ of antibiotic prescriptions received in most parts of Africa do not have a prescription from a clinician while more than $26 \%$ get antibiotics from informal sources ${ }^{3}$. Another study in South Africa established that
$54.9 \%$ of antibiotics prescribed, especially in intensive care units, were inappropriate ${ }^{4}$. Similar findings have been reported in Australia $^{5}$ and in the $\mathrm{USA}^{6}$ indicating that inappropriate use of antibiotics is more of a global issue rather than regional.

Clinicians' and pharmacists' antibiotic prescribing behaviors determine how well the drugs are utilized in hospital settings. Changing prescribers' behaviors is one of the strategies that can reduce misuse and/or overuse of antibiotics in hospital settings. However, sufficient data on this aspect is lacking especially in low- and middle-income countries. This study sought to address this gap by conducting a survey aimed at evaluating the knowledge, attitude, and practices of antibiotic prescription among clinicians in outpatient departments and pharmacies in three counties in Kenya.

\section{Methods}

Study design

The study consisted of a cross-sectional survey of clinicians and pharmacists from public hospitals in three counties in Kenya - Kiambu, Nakuru, and Bungoma (Figure 1). Quantitative data on knowledge, attitude, and practice of antibiotics use/prescription were collected using self-administered questionnaires in six participating facilities. The study is part of a

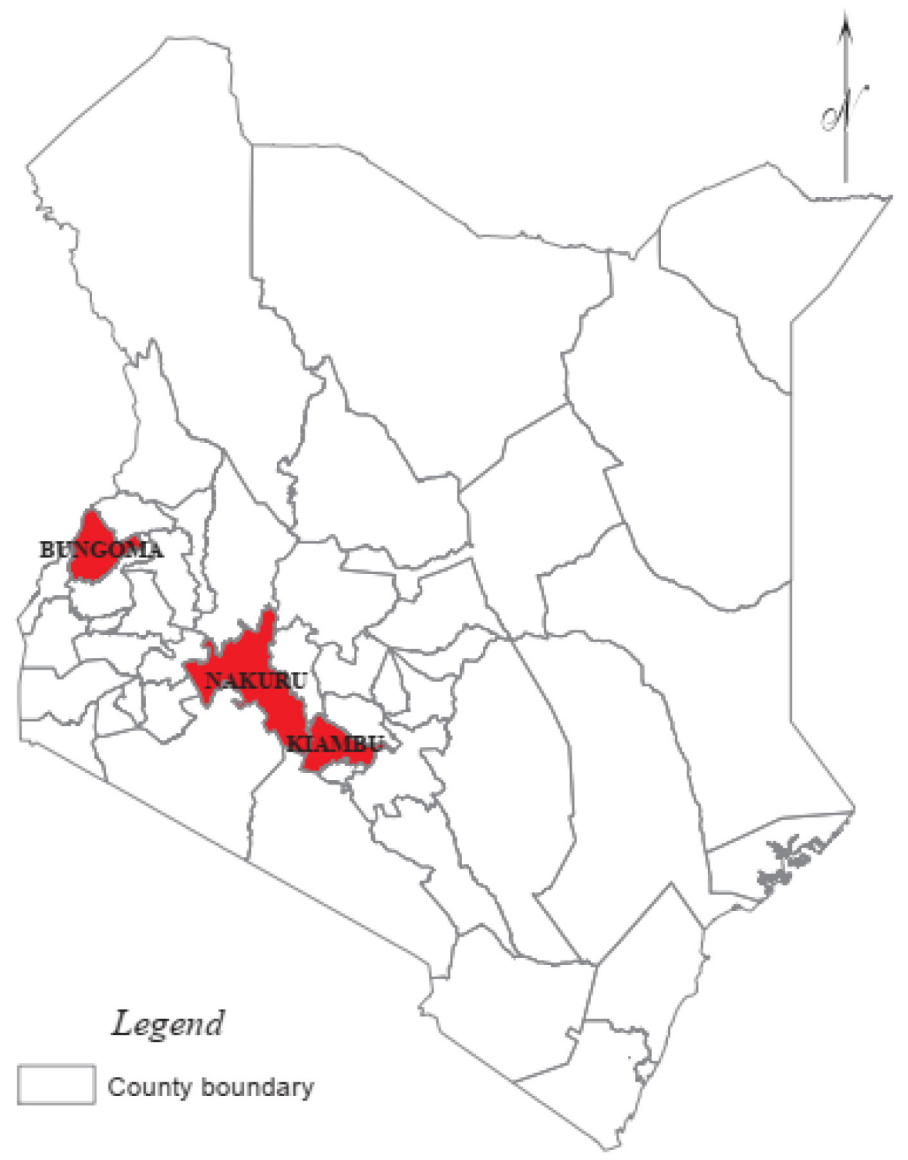

Figure 1. Map of Kenya showing the three counties (Kiambu, Nakuru, and Bungoma) where respondents were surveyed. 
larger project which is ongoing and aims at building stewardship capacity in different hospitals within the three counties ${ }^{7}$.

\section{Study population}

The study targeted medical officers (MOs), medical officer interns (MOIs), clinical officers (COs), clinical officer interns (COIs), and pharmacists who are the medical professional cadres authorized to prescribe antibiotics in hospitals. All the departments with outpatient services in the hospitals were considered eligible for the study. In every hospital, a total of 40 questionnaires were administered and the numbers for each cadre were determined by calculating the proportionate number of staff in each cadre against the total number of staff. This was done by dividing the number of staff in each cadre by the total number of the targeted population in the hospital multiplied by 40 .

\section{Survey instrument}

The study used a structured self-administered questionnaire ${ }^{7}$, which was developed in consultation with experts on antimicrobial resistance as well as previous studies ${ }^{8-10}$. For validation, the questionnaire was first subjected to a pre-testing at Gatundu Level 5 hospital, in Kiambu County, which was not one of the targeted hospitals. The survey instrument was a seven-part series questionnaire, with each series containing a set of questions intended to capture standardized responses. The questions ranged from those targeting general information responses to those that assessed knowledge, attitude, and practice in using antimicrobials. The first part entailed general questions on the number of years the respondent had worked since graduation from medical school, their current department, and designation. The second part comprised of the prescription pattern and the questions included frequency of prescribing antibiotics and use of antibiotic prescription guidelines when prescribing. The third part focused on the awareness and attitude on the current scope of antibiotic resistance while part four required the respondents to describe their confidence in antibiotic knowledge in prescribing and whether they consult their colleagues when prescribing. In part five, the source of information on antibiotic prescription and resistance was sought and part six aimed to know what guides their judgment when prescribing antibiotics. The last part included questions on the knowledge of antibiotic-resistant bacteria and the management of their infections.

\section{Survey administration}

The survey was conducted between $30^{\text {th }}$ April and $11^{\text {th }}$ October 2019. The study team visited each hospital and handed over the questionnaires to the respondents in their workstations after attaining written informed consent from each participant. The completed questionnaires were handed back to the study team with no incentives being offered for participation. To ensure the anonymity of respondents, identifiers were omitted from the questionnaires.

\section{Statistical analysis}

All the filled questionnaires were checked for completeness. Although no questionnaire was excluded entirely due to incompleteness, entries that were incomplete in any questionnaire were excluded from those specific analyses where such entries were needed. Data entry and analysis were carried out using SPSS Statistics version 26.0 (IBM SPSS Statistics, RRID:SCR_019096) (An open-access alternative is R Stats (R Project for Statistical Computing, RRID:SCR_001905)) (The data set is available as underlying data $\left.^{11}\right)$. Simple descriptive statistics were used to generate frequencies, percentages, and proportions. Where necessary, univariate analyses such as Pearson's chi-square were performed to compare proportions for statistical significance.

\section{Ethics statement}

Ethical clearance was obtained from Mount Kenya University Ethics Review Committee (MKU/ERC/0764) and approval to carry out the study was obtained from the National Commission for Science, Technology, and Innovation (NACOSTI) (NACOSTI/P/18/33304/25986). In addition, written permissions were obtained from each of the participating hospitals' administration.

\section{Results}

Two hundred and forty (240) participants from the three counties recorded their responses. By county, there were $72(30 \%)$ from Kiambu, 81 (34.6\%) from Nakuru, and 85 (35.4\%) from Bungoma. The respondents included 135 (56.3\%) clinical officers, 19 (7.9\%) consultants, 66 (27.4\%) medical officers and $20(8.3 \%)$ pharmacists. Among the clinical officers, 76 $(56.3 \%)$ were on internship, $10(7.4 \%)$ had one to three years of experience, $8(5.9 \%)$ had between four and six years of experience and $41(30.4 \%)$ had seven years and above of work experience. Among the medical officers, most of the respondents were interns at $28(42.4 \%)$ and the least were those with one to three years of experience. All the consultants $(n=19)$ who responded had seven or more years of experience while the majority of the pharmacists at $8(40.0 \%)$ had four to six years of work experience (Table 1).

Table 1. Work experience of the respondents classified by the different cadres.

\begin{tabular}{|l|l|l|l|l|}
\hline Work Experience & Clinical Officer & Consultants & Medical Officer & Pharmacist \\
\hline Internship & $76(56.3 \%)$ & $0(0.0 \%)$ & $28(42.4 \%)$ & $1(5.0 \%)$ \\
\hline 1-3 years & $10(7.4 \%)$ & $0(0.0 \%)$ & $11(16.7 \%)$ & $6(30.0 \%)$ \\
\hline 4-6 years & $8(5.9 \%)$ & $0(0.0 \%)$ & $14(21.2 \%)$ & $8(40.0 \%)$ \\
\hline 7 years and above & $41(30.4 \%)$ & $19(100.0 \%)$ & $13(19.7 \%)$ & $5(25.0 \%)$ \\
\hline
\end{tabular}


The majority of the respondents $(55.7 \%)$ indicated that they prescribe to both in- and outpatients while $25.5 \%$ and $18.7 \%$ indicated that they prescribe only to inpatients and outpatients, respectively. More than $70 \%$ of the respondents in each cadre indicated that they prescribed to $50 \%$ (5 out of 10 ) of patients that visited. Among the cadres, only consultants indicated that they do not prescribe antibiotics to all the (10 of 10) patients reviewed (Table 2). Overall, the survey showed that the highest percentage of medical practitioners $(41.8 \%)$ prescribe antibiotics to most (6-9 out of 10) patients while $29.5 \%$ of respondents prescribe antibiotics to at least $50 \%$ of patients (5 out of 10 patients) (Table 2).

To determine the level of knowledge in antibiotics use, eight questions were administered. The respondents earned a single point for every question they answered correctly. From a total score of 8 , the mean score was 4.63 with $78.8 \%$ of the respondents scoring between 4 and 6 . The respondents scored poorest in the questions where no antibiotics were to be used irrespective of the cadre but showed good knowledge on the mode of action of the antibiotics (Table 3). Scores obtained did not significantly differ $(\rho=0.169)$ depending on the years of work experience of the respondents. Generally, the correct responses were highest among consultants, followed by the medical officers then clinical officers.

Most of the respondents agreed or strongly agreed that antibiotic resistance is a problem worldwide $(96.3 \%)$ and in Kenya (92.1\%). However, the proportion of the respondents who either agreed or strongly agreed $(71.6 \%)$ that antibiotic resistance is a problem in their respective health facilities was significantly lower $(\rho=0.013)$ with about $23.8 \%$ of the respondents being neutral about their awareness of an antibiotic resistance problem in their facility (Table 4 ).

On the issue of the reasons fueling antibiotic resistance in the country, most respondents strongly agreed $(31.3 \%, \mathrm{n}=75)$ or agreed $(49.2 \%, \mathrm{n}=118)$ that overuse of antibiotics in hospitals was one of the reasons for increased antibiotic resistance. The other reason was the demand for antibiotics by patients where $25.4 \% \quad(n=61)$ of the respondents strongly agreed and
$42.1 \%(n=101)$ agreed. Increased use of over-the-counter medicine was the other reason with $65 \%(n=156)$ of the respondents strongly agreeing and $29.6 \%(\mathrm{n}=71)$ agreeing (Figure 2).

More than $50 \%$ of the respondents had awareness of local patterns of antibiotic resistance ranging from good to excellent. The rest, $40.4 \%, 6.3 \%$, and $1.7 \%$, indicated that they had an average, very little, and no awareness of local antibiotic patterns, respectively (Figure 3).

On the level of confidence about knowledge on antibiotics and antibiotic prescribing, $20 \%$ of the respondents indicated they were very confident in their antibiotics knowledge and $25.4 \%$ were very confident on antibiotic prescribing. The proportions of those who indicated that they are generally confident, a bit confident, or had no idea about their confidence on either knowledge on antibiotics or antibiotic prescribing are shown in Table 5.

The scores on knowledge about the use of antibiotics were classified as poor (1-4), average (5-6), or excellent (7-8). Although there was a high number of those who scored poorly and indicated that they were confident about their knowledge and in prescribing antibiotics (Table 6), there was no significant correlation between the two $(\rho>0.05)$. In all cadres surveyed, most of the respondents (> 70\%) had an average score level with the clinical officers and pharmacists recording higher numbers of those who performed poorly in the knowledge score (Table 7).

Medical practitioners have a bigger say in ensuring that antibiotics are used judiciously. This can only happen if the medical practitioners are well informed and are up to date with the status of antimicrobial resistance in their facilities and the geographical area covered. To evaluate this aspect, the respondents were asked how they obtained information on antibiotic use. All the listed sources were reported to have been used by more than $50 \%$ of the respondents with the Internet being used by close to $90 \%$ of the respondents (Table 8). In terms of usefulness, all the listed sources were cited as either useful or very useful by more than $80 \%$ of the respondents (Table 9).

Table 2. The average number of patients prescribed antibiotics in every 10 patients reviewed by the medical practitioners.

\begin{tabular}{|l|l|l|l|l|l|}
\hline $\begin{array}{l}\text { Average patients } \\
\text { prescribed AB out of } \mathbf{1 0}\end{array}$ & $\begin{array}{l}\text { Clinical } \\
\text { Officers }\end{array}$ & Consultant & $\begin{array}{l}\text { Medical } \\
\text { Officers }\end{array}$ & Pharmacist & Total \\
\hline All 10 patients & $12(9.0 \%)$ & $0(0.0 \%)$ & $2(3.0 \%)$ & $3(15.8 \%)$ & $17(7.2 \%)$ \\
\hline 6-9 patients & $53(39.8 \%)$ & $7(36.8 \%)$ & $33(50.0 \%)$ & $6(31.6 \%)$ & $99(41.8 \%)$ \\
\hline 5 patients & $40(30.1 \%)$ & $7(36.8 \%)$ & $16(24.2 \%)$ & $7(36.8 \%)$ & $70(29.5 \%)$ \\
\hline $1-4$ patients & $27(20.3 \%)$ & $5(26.3 \%)$ & $15(22.7 \%)$ & $2(10.5 \%)$ & $49(20.7 \%)$ \\
\hline None & $1(0.8 \%)$ & $0(0.0 \%)$ & $0(0.0 \%)$ & $1(5.3 \%)$ & $2(0.8 \%)$ \\
\hline
\end{tabular}

AB: antibiotic 
Table 3. Questions on antibiotic knowledge and their results.

\begin{tabular}{|c|c|c|c|c|c|c|}
\hline Question & $\begin{array}{l}\text { Overall N } \\
\text { (\%) } \\
\text { answered } \\
\text { correctly. }\end{array}$ & $\begin{array}{l}\mathrm{N}(\%) \text { of } \\
\text { COs } \\
\text { answered } \\
\text { correctly }\end{array}$ & $\begin{array}{l}\mathbf{N}(\%) \text { of } \\
\text { Consultants } \\
\text { answered } \\
\text { correctly }\end{array}$ & $\begin{array}{l}\text { N (\%) of } \\
\text { MO } \\
\text { answered } \\
\text { correctly }\end{array}$ & $\begin{array}{l}\mathrm{N}(\%) \text { of } \\
\text { pharmacists } \\
\text { answered } \\
\text { correctly }\end{array}$ & $\rho$ \\
\hline $\begin{array}{l}\text { 1. A 4-year-old child had diarrhoea in the last } 4 \text { days (3 } \\
\text { stools daily). She had no fever during the past days } \\
\text { nor at consultation. What is your treatment choice? } \\
\text { a) Amoxicillin orally } \\
\text { b) Trimethoprim/sulphamethoxazole orally } \\
\text { c) Amoxicillin/clavulanic acid orally } \\
\text { d) Oral rehydration salts with no antibiotic }\end{array}$ & $\begin{array}{l}228 / 236 \\
(96.6 \%)\end{array}$ & $\begin{array}{l}127 / 132 \\
(96.2 \%)\end{array}$ & $\begin{array}{l}19 / 19 \\
(100.0 \%)\end{array}$ & $\begin{array}{l}64 / 65 \\
(98.5 \%)\end{array}$ & $\begin{array}{l}18 / 20 \\
(90.0 \%)\end{array}$ & 0.253 \\
\hline $\begin{array}{l}\text { 2. A 6-year-old child has a fever }\left(38^{\circ} \mathrm{C}\right) \text {, nasal discharge, } \\
\text { and a painful throat for two days. At visual inspection, } \\
\text { the throat is reddish. What is your treatment choice? } \\
\text { a) Trimethoprim/sulphamethoxazole orally } \\
\text { b) Amoxicillin orally } \\
\text { c) Amoxicillin/clavulanic acid orally } \\
\text { d) No antibiotic }\end{array}$ & $\begin{array}{l}23 / 230 \\
(10.0 \%)\end{array}$ & $\begin{array}{l}10 / 128 \\
(7.8 \%)\end{array}$ & $\begin{array}{l}04 / 19 \\
(21.1 \%)\end{array}$ & $\begin{array}{l}8 / 64 \\
(12.5 \%)\end{array}$ & $\begin{array}{l}1 / 19 \\
(5.3 \%)\end{array}$ & 0.243 \\
\hline $\begin{array}{l}\text { 3. During ward round, you have seen two patients with } \\
\text { impaired renal function. } \\
\text { - Patient A is a 68-year-old male with cellulitis in the } \\
\text { lower limb. He is administered clindamycin. } \\
\text { - Patient B is a 64-year-old woman with diabetes } \\
\text { who received treatment for sepsis with ceftriaxone } \\
\text { empirically. } \\
\text { In which case will you need to adjust the antibiotic dose? } \\
\text { a) Patient A } \\
\text { b) Patient B } \\
\text { c) Patient A \& B } \\
\text { d) Neither patient A nor patient B }\end{array}$ & $\begin{array}{l}26 / 232 \\
(11.2 \%)\end{array}$ & $\begin{array}{l}21 / 131 \\
(16.0 \%)\end{array}$ & $\begin{array}{l}1 / 19 \\
(5.6 \%)\end{array}$ & $\begin{array}{l}4 / 66 \\
(6.3 \%)\end{array}$ & $\begin{array}{l}0 / 20 \\
(0.0 \%)\end{array}$ & 0.055 \\
\hline $\begin{array}{l}\text { 4. Which one of the following antibiotics may be safely } \\
\text { given during the first trimester of pregnancy? } \\
\text { a) Amoxicillin } \\
\text { b) Ciprofloxacin } \\
\text { c) Gentamicin }\end{array}$ & $\begin{array}{l}220 / 233 \\
(94.4 \%)\end{array}$ & $\begin{array}{l}121 / 130 \\
(93.1 \%)\end{array}$ & $\begin{array}{l}18 / 19 \\
(94.7 \%)\end{array}$ & $\begin{array}{l}62 / 66 \\
(96.9 \%)\end{array}$ & $\begin{array}{l}19 / 20 \\
(95.0 \%)\end{array}$ & 0.755 \\
\hline $\begin{array}{l}\text { 5. Which of the following antibiotics has the best activity } \\
\text { against anaerobes? } \\
\text { a) Ciprofloxacin } \\
\text { b) Metronidazole } \\
\text { c) Trimethoprim/sulphamethoxazole }\end{array}$ & $\begin{array}{l}219 / 234 \\
(93.5 \%)\end{array}$ & $\begin{array}{l}124 / 131 \\
(94.7 \%)\end{array}$ & $\begin{array}{l}19 / 19 \\
(100.0 \%)\end{array}$ & $\begin{array}{l}61 / 66 \\
(95.3 \%)\end{array}$ & $\begin{array}{l}15 / 20 \\
(75.0)\end{array}$ & 0.004 \\
\hline $\begin{array}{l}\text { 6. Methicillin-resistant - Staphylococcus aureus is } \\
\text { susceptible to: } \\
\text { a) Amoxicillin clavulanic acid } \\
\text { b) Cefotaxime } \\
\text { c) Ceftriaxone } \\
\text { d) None of these antibiotics }\end{array}$ & $\begin{array}{l}83 / 222 \\
(37.3 \%)\end{array}$ & $\begin{array}{l}21 / 135 \\
16.9 \%\end{array}$ & $\begin{array}{l}12 / 19 \\
70.6 \%\end{array}$ & $\begin{array}{l}42 / 62 \\
67.7 \%\end{array}$ & $\begin{array}{l}8 / 19 \\
42.1 \%\end{array}$ & 0.0001 \\
\hline $\begin{array}{l}\text { 7. Which of the following antibiotics most effectively } \\
\text { crosses the blood-brain barrier? } \\
\text { a) Clindamycin } \\
\text { b) Ceftriaxone } \\
\text { c) Vancomycin }\end{array}$ & $\begin{array}{l}151 / 226 \\
(66.8 \%)\end{array}$ & $\begin{array}{l}75 / 124 \\
60.5 \%\end{array}$ & $\begin{array}{l}16 / 19 \\
84.2 \%\end{array}$ & $\begin{array}{l}45 / 64 \\
70.3 \%\end{array}$ & $\begin{array}{l}15 / 19 \\
78.9 \%\end{array}$ & 0.092 \\
\hline $\begin{array}{l}\text { 8. Aminoglycoside antibiotics such as gentamicin are } \\
\text { most active when they are administered as follows: } \\
\text { a) Orally, three times daily } \\
\text { b) Parenterally, once daily } \\
\text { c) Parenterally, three times daily }\end{array}$ & $\begin{array}{l}162 / 231 \\
(70.1 \%)\end{array}$ & $\begin{array}{l}90 / 129 \\
69.8 \%\end{array}$ & $\begin{array}{l}13 / 19 \\
68.4 \%\end{array}$ & $\begin{array}{l}49 / 63 \\
77.8 \%\end{array}$ & $\begin{array}{l}10 / 20 \\
50.0 \%\end{array}$ & 0.129 \\
\hline
\end{tabular}

$\mathrm{N}$ : number; COs: Clinical Officers; MO: Medical Officers 
Table 4. Perception of antibiotic resistance as a problem.

\begin{tabular}{|l|l|l|l|}
\hline $\begin{array}{l}\text { Antibiotic } \\
\text { resistance problem }\end{array}$ & Worldwide & Kenya & $\begin{array}{l}\text { Health } \\
\text { facilities }\end{array}$ \\
\hline I strongly agree & $135(56.3 \%)$ & $126(52.5 \%)$ & $56(23.3 \%)$ \\
\hline I agree & $96(40 \%)$ & $95(39.6 \%)$ & $116(48.3 \%)$ \\
\hline Neutral & $8(3.3 \%)$ & $16(6.7 \%)$ & $57(23.8 \%)$ \\
\hline I disagree & $1(0.4 \%)$ & $3(1.3 \%)$ & $11(4.6 \%)$ \\
\hline
\end{tabular}

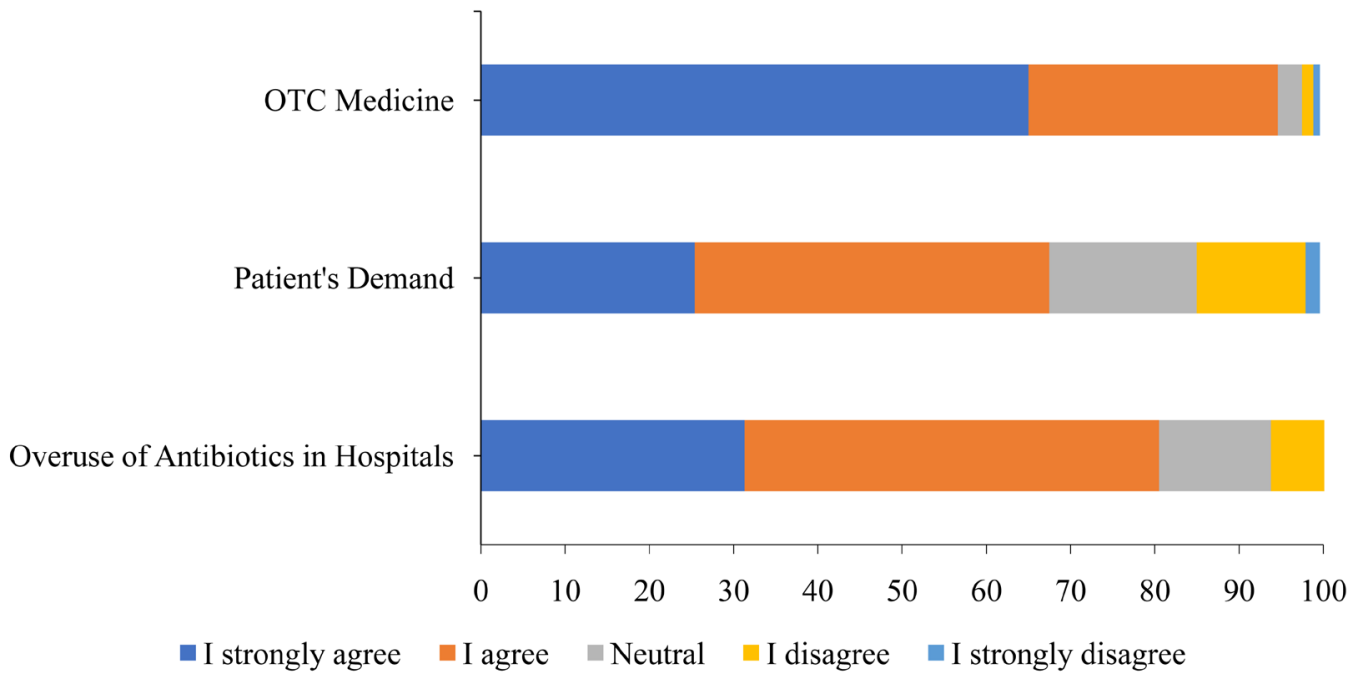

Figure 2. Reasons for the antibiotic resistance problem in Kenya.

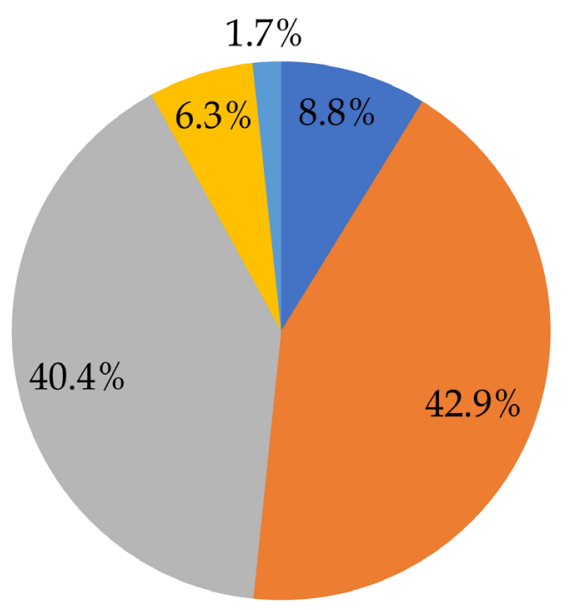

Excellent $\square$ Good $\square$ Average $\square$ Very little $\square$ None

Figure 3. Awareness of local antibiotic resistance patterns. 
Table 5. Level of confidence on antibiotic knowledge or prescribing antibiotics by the respondents.

\begin{tabular}{|l|l|l|}
\hline & \multicolumn{2}{|c|}{ Confidence on } \\
\hline Confidence level & Antibiotic knowledge & Prescribing antibiotics \\
\hline Very confident & $48(20 \%)$ & $61(25.4 \%)$ \\
\hline Confident & $166(69.2 \%)$ & $157(65.4 \%)$ \\
\hline A bit confident & $25(10.4 \%)$ & $19(7.9 \%)$ \\
\hline Neutral/I have no idea & $1(0.4 \%)$ & $3(1.3 \%)$ \\
\hline
\end{tabular}

Table 6. Level of confidence on knowledge and prescribing antibiotics and the score levels.

\begin{tabular}{|l|l|l|l|l|l|l|l|l|}
\hline \multicolumn{4}{|c|}{$\begin{array}{l}\text { How confident are you about your } \\
\text { knowledge of antibiotics? }\end{array}$} & \multicolumn{4}{l}{ What is your confidence level in prescribing } \\
antibiotics?
\end{tabular}

Table 7. Knowledge score on antibiotics use among the different cadres based on the answers given in knowledge questions.

\begin{tabular}{|l|l|l|l|l|l|}
\hline Score Level & CO & Consultant & MO & Pharmacist & P \\
\hline Poor & $23(17.0 \%)$ & $1(5.3 \%)$ & $6(9.1 \%)$ & $6(30.0 \%)$ & 0.033 \\
\hline Average & $107(79.3 \%)$ & $15(78.9 \%)$ & $53(80.3 \%)$ & $14(70.0 \%)$ & \\
\hline Excellent & $5(3.7 \%)$ & $3(15.8 \%)$ & $7(10.6 \%)$ & $0(0.0 \%)$ & \\
\hline
\end{tabular}

CO: Clinical Officer; MO: Medical Officer. The scores were classified as poor (1-4), average (5-6), or excellent (7-8).

\section{Table 8. Sources of information on antibiotic use consulted in the last month.}

\begin{tabular}{|l|l|}
\hline Source of information consulted in the last month & N (\%) \\
\hline Information supplied by pharmaceutical companies & $123(51.2 \%)$ \\
\hline Knowledge from training institutions & $156(65 \%)$ \\
\hline Internet & $214(89.2 \%)$ \\
\hline National guideline for empiric antimicrobial therapy & $161(67.1 \%)$ \\
\hline The World Health Organization's (WHO) guidelines for the treatment of bacterial diseases & $168(70 \%)$ \\
\hline
\end{tabular}

We aimed to find out at which level the respondents agreed to the fact that patient demand for antibiotics and medicine sold over-the-counter contributes to antibiotic resistance. The results showed that more than $67 \%$ agreed or strongly agreed that patient demand is a major contributor to antibiotic resistance while more than $95 \%$ agreed or strongly agreed that 


\begin{tabular}{|c|c|c|}
\hline Source of information & & Frequency \\
\hline \multirow[t]{5}{*}{ Information supplied by pharmaceutical companies } & Very useful & $48(20 \%)$ \\
\hline & Useful & $161(67.1 \%)$ \\
\hline & Not at all useful & $15(6.3 \%)$ \\
\hline & I do not know & $9(3.8 \%)$ \\
\hline & No Answer & $7(2.9 \%)$ \\
\hline \multirow[t]{5}{*}{ Knowledge from training institution } & Very useful & $123(51.2 \%)$ \\
\hline & Useful & $94(39.2 \%)$ \\
\hline & Not at all useful & $1(0.4 \%)$ \\
\hline & I do not know & $14(5.8 \%)$ \\
\hline & No Answer & $8(3.3 \%)$ \\
\hline \multirow[t]{5}{*}{ Internet } & Very useful & $90(37.5 \%)$ \\
\hline & Useful & $136(56.7 \%)$ \\
\hline & Not at all useful & $7(2.9 \%)$ \\
\hline & I do not know & $4(1.7 \%)$ \\
\hline & No Answer & $3(1.3 \%)$ \\
\hline \multirow[t]{5}{*}{ National guideline for empiric antimicrobial therapy } & Very useful & $131(54.6 \%)$ \\
\hline & Useful & $78(32.5 \%)$ \\
\hline & Not at all useful & $1(0.4 \%)$ \\
\hline & I do not know & $24(10 \%)$ \\
\hline & No answer & $6(2.5 \%)$ \\
\hline \multirow[t]{5}{*}{$\begin{array}{l}\text { The World Health Organization's guidelines for the } \\
\text { treatment of bacterial diseases }\end{array}$} & Very useful & 140 (58.3\%) \\
\hline & Useful & $72(30 \%)$ \\
\hline & Not at all useful & $2(0.8 \%)$ \\
\hline & I do not know & $17(7.1 \%)$ \\
\hline & No answer & $9(3.8 \%)$ \\
\hline
\end{tabular}

over-the-counter medicine is a huge contributor to antibiotic resistance (Table 10).

Even though most of the respondents agreed that patient demand and over-the-counter medications are the main contributors to antibiotic resistance, there was a high number who indicated that they do not depend on antibiotic sensitivity data to vary their prescription. In all the six facilities, more than $20 \%$ of the respondents stated they never use antibiotic sensitivity data while $51.5 \%$ stated that they only do so sometimes (Table 11).

\section{Discussion}

The present study describes the results of a survey on knowledge, attitude, and practice on the prescription of antibiotics among medical practitioners in three counties in Kenya. The study targeted the clinicians and pharmacists, who are the primary antibiotics prescribers in hospitals. Most of the respondents were aware that antibiotic resistance is a global and national problem, although few admitted that it is a problem in their local facilities. These results mirror previously reported studies where the respondents rated lower existence of antibiotic resistance in their facilities compared with either nationally 


\title{
Table 10. Contributors of antimicrobial resistance.
}

\begin{tabular}{|l|l|l|}
\hline & $\begin{array}{l}\text { Contributors of antibiotic } \\
\text { resistance }\end{array}$ \\
\hline Response & Patient's demand & OTC medicine \\
\hline I strongly agree & $61(25.5 \%)$ & $156(65.3 \%)$ \\
\hline I agree & $101(42.3 \%)$ & $71(29.7 \%)$ \\
\hline Neutral & $42(17.5 \%)$ & $7(2.9 \%)$ \\
\hline I disagree & $31(13 \%)$ & $3(1.3 \%)$ \\
\hline I strongly disagree & $4(1.7 \%)$ & $2(0.8 \%)$ \\
\hline OTC: over-the-counter & & \\
\hline
\end{tabular}

\begin{abstract}
Table 11. How often do you depend on antibiotic sensitivity data from the laboratory to vary your prescription?
\end{abstract}

\begin{tabular}{|l|l|l|l|l|l|l|l|}
\hline & Kiambu & Thika & Nakuru & Naivasha & Bungoma & Webuye & Total \\
\hline Never & $17(40.5 \%)$ & $6(22.2 \%)$ & $10(22.7 \%)$ & $8(20.5 \%)$ & $8(20.0 \%)$ & $11(24.4 \%)$ & $60(25.3 \%)$ \\
\hline Sometimes & $19(45.2 \%)$ & $16(59.3 \%)$ & $22(50.0 \%)$ & $21(53.8)$ & $22(55.0 \%)$ & $22(48.9 \%)$ & $122(51.5 \%)$ \\
\hline Half of the times & $3(7.1 \%)$ & $0(0.0 \%)$ & $3(6.8 \%)$ & $4(10.3 \%)$ & $2(5.0 \%)$ & $4(8.9 \%)$ & $16(6.8 \%)$ \\
\hline Mostly & $3(7.1 \%)$ & $5(18.5 \%)$ & $5(11.4 \%)$ & $4(10.3 \%)$ & $5(12.5 \%)$ & $8(17.8 \%)$ & $30(12.7 \%)$ \\
\hline Always & $0(0.0 \%)$ & $0(0.0 \%)$ & $4(9.1 \%)$ & $2(5.1 \%)$ & $3(7.5 \%)$ & $0(0.0 \%)$ & $9(3.8 \%)$ \\
\hline
\end{tabular}

or globally ${ }^{12-14}$. This signals a dangerous trend given that these are the primary levels from where antibiotic resistance begins. Overall, the survey showed that the highest percentage of medical practitioners $(41.8 \%)$ prescribe antibiotics to most (6-9 out of 10) of their patients. This is an alarming number considering that most of these hospitals do not perform culture and sensitivity tests for most of these cases, and most of them state that they rarely depend on antibiotic sensitivity data when prescribing antibiotics.

There was a high level of self-confidence reported among the respondents both in their knowledge and in prescribing antibiotics. Although a high number of respondents scored poorly in the knowledge score, they at the same time indicated to be confident about their knowledge and in prescribing antibiotics. In addition, the respondents who were either medical officers or consultants scored higher in the knowledge score than either clinical officers or pharmacists. This could be due to the advanced training that medical officers and consultants undergo. This also highlights the importance of targeting the clinical officers for future educational interventions on antibiotic use. Similar findings have been reported in Ghana where senior physicians had better knowledge on those bacteria that have developed resistance in their setting compared with junior physicians $^{12}$.
On average, the respondents scored 4.63 out of the possible 8 points in the knowledge questions. This was slightly lower than the results reported in the Democratic Republic of Congo (DRC) targeting medical doctors and students where the respondents scored $4.9 / 8^{15}$ and in Peru with a score of $6.0 / 7^{16}$. The low score was contributed to by the poor performance in three of the eight questions that were on the use of antibiotics in upper respiratory tract infection, antibiotics that are effective in treating methicillin-resistant, for example, Staphylococcus aureus, and antibiotic reduction in renal failure conditions. Interestingly, responses to these same questions performed poorly in a study conducted in $\mathrm{DRC}^{15}$, suggesting that this challenge goes beyond local or national boundaries.

The antibiotic resistance profile is dynamic, with novel resistant strains emerging often and making common infections either difficult or impossible to treat ${ }^{17}$. To curtail the misuse and overuse of antibiotics, there is a need for the prescribers to be well updated on the appropriate use of antibiotics. Most respondents in our study indicated that the knowledge they have on antibiotics and antibiotic resistance is from either the Internet, knowledge attained in training institutions, pharmaceutical companies, or the World Health Organization (WHO) guidelines. Generally, most respondents indicated that they sourced their information from the Internet because almost 
all documents are posted as soft copies online. In agreement with previous studies ${ }^{16,18}$, our findings also highlight the role played by the Internet in health service delivery. However, Internet access has also been cited as one of the factors that have enhanced the self-medication of antibiotics in the recent past ${ }^{19}$.

In terms of the value of the acquired information, the WHO guidelines ranked top, followed by national guidelines, and then training institutions. Most respondents, however, affirmed that local guidelines were more important than the global guidelines because they are contextualized to the local needs and antimicrobial resistance profile. Indeed, previous studies have reported commendable compliance with the Kenya Essential Medicines List in antibiotic prescribing in some of the public hospitals ${ }^{20}$. Even though the value of the knowledge attained from training institutions was graded lowest, it was still useful because any gaps in knowledge could be addressed at the training stages.

Previous studies have pointed out that pressure from patients to prescribe antibiotics plays a crucial role in inappropriate use leading to antibiotic resistance ${ }^{16,21,22}$. In this study, the majority of the respondents agreed or strongly agreed that patients' demand for antibiotics and the over-the-counter acquisition are huge contributors to antibiotic resistance.

\section{Conclusion}

The present study revealed that most medical practitioners in Kenya are aware and knowledgeable about antibiotic resistance. There is, however, a need for educational interventions to sensitize medical practitioners on their attitude and excessive or unnecessary prescription of antibiotics. Although the study targeted antibiotic prescribers in different cadres and geographical locations in Kenya, there is still the need to expand the study to vast parts of the country as our study focused on just three out of 47 counties.

\section{Data availability}

Underlying data

Mendeley data: Underlying data for 'A survey on knowledge, attitudes, and practice about antibiotic prescribing and resistance among medical practitioners in Kenya'. https://doi. org/10.17632/fmw97xwvdt. $2^{11}$.

This project contains the following underlying data:

- Data file: Knowledge, Attitude and Practice Survey in Kenya - Baseline Data 1.xlsx

\section{Extended data}

Mendeley data: Extended data for 'A survey on knowledge, attitudes, and practice about antibiotic prescribing and resistance among medical practitioners in Kenya'. https://doi. org/10.17632/fmw97xwvdt.2 ${ }^{11}$

This project contains the following extended data:

- Questionnaire: KAP data collection tool.pdf

Data are available under the terms of the Creative Commons Attribution 4.0 International license (CC-BY 4.0).

\section{Consent}

Written informed consent for publication of the participants' details was obtained from the participants.

\section{Acknowledgements}

We thank all medical workers who participated in responding to the questionnaires. We would also like to thank the administrations in all the six hospitals for their cooperation and support during data collection.
1. Prestinaci F, Pezzotti P, Pantosti A: Antimicrobial resistance: A global multifaceted phenomenon. Pathog Glob Health. Maney Publishing, 2015; 109(7): 309-318.

PubMed Abstract | Publisher Full Text | Free Full Text

2. Hoffman SB: Mechanisms of Antibiotic Resistance. Compend Contin Educ Pract Vet. 2001; 23(5): 464-472.

Reference Source

3. Vialle-Valentin CE, Lecates RF, Zhang $F$, et al:: Predictors of antibiotic use in African communities: Evidence from medicines household surveys in five countries. Trop Med Int Health. 2012; 17(2): 211-222. PubMed Abstract | Publisher Full Text

4. Paruk F, Richards G, Scribante J, et al:: Antibiotic prescription practices and their relationship to outcome in South Africa: findings of the prevalence of infection in South African intensive care units (PISA) study. 5 Afr Med J. 2012; 102(7): 613-6. PubMed Abstract | Publisher Full Text

5. Ingram PR, Seet JM, Budgeon CA, et al.: Point-prevalence study of inappropriate antibiotic use at a tertiary Australian hospital. Intern Med J.
2012; 42(6): 719-721.

PubMed Abstract | Publisher Full Text

6. Fridkin SK, Baggs J, Fagan R, et al.: Vital Signs: Improving Antibiotic Use Among Hospitalized Patients. MMWR Morb Mortal Wkly Rep. 2014; 63(9): 194-200.

PubMed Abstract | Free Full Text

7. Gitaka J, Kamita M, Mureithi D, et al.: Combating antibiotic resistance using guidelines and enhanced stewardship in Kenya: A protocol for an implementation science approach. BMJ Open. 2020; 10(3): e030823. PubMed Abstract | Publisher Full Text | Free Full Text

8. Teixeira Rodrigues A, Roque F, Falcão A, et al.: Understanding physician antibiotic prescribing behaviour: A systematic review of qualitative studies. Int J Antimicrob Agents. Elsevier B.V., 2013; 41(3): 203-212. PubMed Abstract | Publisher Full Text

9. Teixeira Rodrigues A, Ferreira M, Roque F, et al.: Physicians' attitudes and knowledge concerning antibiotic prescription and resistance: Questionnaire development and reliability. BMC Infect Dis. 2016; 16: 7. PubMed Abstract | Publisher Full Text | Free Full Text 
10. Fathi I, Sameh O, Abu-Ollo M, et al.: Knowledge, Attitudes, and Beliefs Regarding Antimicrobial Therapy and Resistance among Physicians in Alexandria University Teaching Hospitals and the Associated Prescription Habits. Microb Drug Resist. 2017; 23(1): 71-78. PubMed Abstract | Publisher Full Text

11. Kamita M, et al.: A Survey on Knowledge, Attitudes, and Practice About Antibiotic Prescribing and Resistance Among Medical Practitioners in Kenya - Mendeley Data. (accessed Nov. 22, 2021). https://data.mendeley.com/drafts/fmw97xwvdt

12. Nicholson A, Tennant I, White L, et al:: Correction to: The knowledge, attitudes and practices of doctors regarding antibiotic resistance at a tertiary care institution in the Caribbean. Antimicrob Resist Infect Control. 2018; 7: 77.

PubMed Abstract | Publisher Full Text | Free Full Text

13. Sellman JS, Decarolis D, Schullo-Feulner A, et al.: Information resources used in antimicrobial prescribing. J Am Med Inform Assoc. 2004; 11(4): 281-284. PubMed Abstract | Publisher Full Text | Free Full Text

14. Wester CW, Durairaj L, Evans AT, et al.: Antibiotic resistance: A survey of physician perceptions. Arch Intern Med. 2002; 162(19): 2210-2216. PubMed Abstract | Publisher Full Text

15. Thriemer K, Katuala Y, Batoko B, et al.: Antibiotic Prescribing in DR Congo: A Knowledge, Attitude and Practice Survey among Medical Doctors and Students. PLoS One. 2013; 8(2): e55495.

PubMed Abstract | Publisher Full Text | Free Full Text

16. García C, Llamocca LP, García K, et al.: Knowledge, attitudes and practice survey about antimicrobial resistance and prescribing among physicians in a hospital setting in Lima, Peru. BMC Clin Pharmacol. 2011; 11: 18. PubMed Abstract | Publisher Full Text | Free Full Text

17. Neely AN, Holder IA: Antimicrobial resistance. Burns. 1999; 25(1): 17-24. PubMed Abstract | Publisher Full Text

18. Khan AKA, Banu G, Reshma KK: Antibiotic resistance and usage-a survey on the knowledge, attitude, perceptions and practices among the medical students of a southern Indian teaching hospital. J Clin Diagn Res. 2013; 7(8): students of

PubMed Abstract | Publisher Full Text | Free Full Text

19. Sundararajan A, Thangappan AK: Knowledge, attitude and practice of self medication among undergraduate medical students in a teaching institution. Int J Basic Clin Pharmacol. 2018; 7(12): 2414. Publisher Full Text

20. Mulwa NC, Osanjo GO, Ndwigah SN, et al:: Patterns of Prescribing Practices in Makueni County Referral Hospital, Kenya. 2015; 4(4): 161-168. Reference Source

21. Saliba-Gustafsson EA, Dunberger Hampton A, Zarb P, et al.: Factors associated with antibiotic prescribing in patients with acute respiratory tract complaints in Malta: A 1-year repeated cross-sectional surveillance study. BMJ Open. 2019; 9(12): e032704.

PubMed Abstract | Publisher Full Text | Free Full Text

22. Lin L, Sun $R$, Yao T, et al.: Factors influencing inappropriate use of antibiotics in outpatient and community settings in China: A mixed-methods systematic review. BMJ Glob Health. BMJ Publishing Group, 2020; 5(11): e003599.

PubMed Abstract | Publisher Full Text | Free Full Text 